\title{
Growing Population of Elderly in Europe - A Wake Up Call for Social Services Expansion
}

M. Bartkovjak (Marian Bartkovjak)1', M. Olah (Michal Olah)5,6 V. Krcmery (Vladimir Krcmery)1,2, A. Nemcokova (Adriana Nemcokova)4 ${ }^{4}$ D. West (Daniel West)3, M. Zavis (Monika Zavis) ${ }^{7}$

${ }^{1}$ St. Lesley College, Maternal Health Unit - SAMRS development

Original Article program, Gordhim, South Sudan

2 School of Medicine, Comenius University, Bratislava, Slovakia

${ }^{3}$ University of Scranton, Panuska School of Professional Studies, Scranton, PA, USA

${ }^{4}$ St. Elizabeth University, Bl. Sara Salkahazi, Roznava, Slovakia

${ }^{5}$ PRIGO University, Havirov, Czech Republic

${ }^{6}$ St. Elisabeth University, Dr. P. Blaho, Skalica, Slovakia

${ }^{7}$ Comenius University in Bratislava, Slovakia

\section{E-mail address:}

bartkovjak@yahoo.com

\section{Reprint address:}

Marian Bartkovjak

St. Lesley College, Maternal Health Unit - SAMRS development program

Gordhim

South Sudan

Source: Clinical Social Work and Health Intervention

Volume: 10

Issue: 2

Pages: $22-24$

Cited references: 3

\section{Reviewers:}

Andrea Shahum

University of North Carolina at Chapel Hill School of Medicine, USA

Ivan Bartosovic

St. Elisabeth University of Health and Social Work, Slovakia

\section{Key words:}

Growning Population. Demographic Changes. Europe. Social Services.

\section{Publisher:}

International Society of Applied Preventive Medicine i-gap

CSWHI 2019; 10(2): 22 - 24; DOI 10.22359/cswhi_10_2_03 ㅇ 2019 Clinical Social Work and Health Intervention 


\section{Abstract:}

Certain demographic changes nowadays, such as declining natality, increased life expectancy at birth and at retirement, will lead to an increase in the population of seniors for which society is unprepared and demand for social services will increase. How are we prepared today will predict the future for seniors tomorrow.

\section{Introduction}

Demographic developments in Europe have shown several warning signs over the past few years, such as declining natality, a population of average life expectancy at risk of civilization diseases; increased life expectancy at retirement; increased demand and the need for social services in the elderly cohort. Declining natality in Europe (0.81.2 child per woman) is an alarming state, which may be slightly adjusted by influx of migrants especially young families or by supporting family policies in European families.

\section{Are we ready for seniors?}

Increasing life expectancy itself is a positive phenomenon in society, both globally and locally, as it is usually the result of a lifestyle change influenced by public health professionals who promote healthy food, exercise, and preventive examinations. In addition, health systems are contributing to reducing cardiovascular risk; cancer-related mortality; addictions; or traumatic accidents. This is particularly highlighted in the countries of Europe, North America and the Western Pacific (Japan, Taiwan, Hong Kong, Singapore), where life expectancy exceeds 80 years. In addition to the way of life, there is a key role too in eating habits, which increases life expectancy especially in the Mediterranean, Scandinavia, Japan and China. This positive phenomenon also has an economic impact, as people in the $60 \mathrm{~s}$ are still working and are thus of benefit for the economies of the individual countries.
This leads states in Europe to prolonge retirement age in order to prevent an increase in pension expenditure for the growing generation of seniors.

\section{Conclusion}

If we expect an increase in the population of seniors who are economically active and pay one of the highest taxes to the state, we must also adapt social services so that they receive adequate care for their taxes. And this is a challenge for the country's health systems as this problem will worsen directly in proportion to the growing senior population. Services such as nursing care, long-term illnesses centres, day care centers and hospices are in many countries undersized by both staff and equipment, and the number of beds is also insufficient. The challenge is therefore to ensure:

a) sufficient number of beds (infrastructure);

b) personnel (by popularizing professions and opening up new university programmes);

c) equipping seniors' facilities (by releasing of funds).

\section{References}

1. TENTH ANNUAL REPORT BY THE EUROPEAN STATISTICAL GOVERNANCE ADVISORY BOARD TO THE EUROPEAN PARLIAMENT AND THE COUNCIL ON THE IMPLEMENTATION OF THE EUROPEAN STATISTICS CODE OF 
PRACTICE BY EUROSTAT AND THE EUROPEAN STATISTICAL SYSTEM AS

A WHOLE (2019). Publications Office of the European Union, ISBN 978-92-79-96725-2 ISSN 2443-8057 doi:10.2785/747404.

2. CEPOVA E, KOLARCIK P, MADARASOVA GECKOVA A (2017) Health literacy, method as improve health population and exploitation in public health. In: Health and Social Work. ISSN 13336-9326. Vol. 12, No 1, p. 25-33.

3. ANNUAL REPORT ON EVALUATION 2017 (June 2018) Independent Evaluation Office of UNDP, New York,. 